\title{
DOSSIER
}

\section{Paradoxes de la communication numérique de recrutement, le cas des banques entre marque employeur et isomorphisme numérique}

\author{
Daniel Pélissier ${ }^{1}$
}

Résumé : la communication numérique de recrutement des banques est un construit orienté, notamment par l'usage de la marque employeur et de l'isomorphisme numérique. Cette recherche montre comment de jeunes diplômés, cibles privilégiées de ces messages, reçoivent les données consultées sur l'internet. Le cas de la BNP Paribas est étudié à travers des discours individuels recueillis au cours d'entretiens d'autoconfrontation. Les résultats montrent les paradoxes du transfert du concept marketing de marque employeur au recrutement. Par ailleurs, ils soulignent les limites de l'isomorphisme numérique. La position externaliste du chercheur est enfin questionnée.

Mots-clés : recrutement, marque employeur, représentation sociale.

Paradoxes in digital recruitment communication, the cases of banks, between employer brand and digital isomorphism

\begin{abstract}
Digital recruitment by banks is oriented by the use of the employer brand and digital isomorphism. This research work shows how young graduates, privileged targets of these messages, receive data consulted on the Web. BNP Paribas is studied through the individual speeches collected during self-confrontation interviews. Results show the paradoxes of the transfer of the employer's brand marketing concept to recruitment. Moreover, they emphasize the limits of digital isomorphism. The exterior position of the researcher is finally questioned.
\end{abstract}

Keywords: recruitment, employer brand, social representation.

1- Daniel Pélissier a soutenu une thèse en Sciences de l'Information et de la Communication sur les paradoxes communicationnels du recrutement sous la direction de Martine CorralRegourd et Robert Boure. Il est rattaché au laboratoire IDETCOM, université Toulouse 1 Capitole ; daniel2.pelissier@ut-capitole.fr

Communication \& Organisation 53, juin 2018, p. 39-52. 